\title{
Apple aphid, Aphis spp. (Hemiptera: Aphididae), and predator populations in an apple orchard at the non-bearing stage: The impact of ground cover and cultivar
}

\author{
Bruno FRÉCHETTE ${ }^{1}$, Daniel CORMIER ${ }^{2}$, Gérald CHOUINARD ${ }^{2}$, Franz VANOOSTHUYSE ${ }^{2}$ and Éric LUCAS ${ }^{1}$ \\ ${ }^{1}$ Université du Québec à Montréal (UQAM), Groupe de Recherche en Écologie Comportementale et Animale (GRECA), \\ Département des Sciences Biologiques, C.P. 8888, Succ. Centre-Ville, Montréal, Québec, H3C 3P8 Canada; \\ e-mail: frechette_bruno@yahoo.ca \\ ${ }^{2}$ Institut de Recherche et de Développement en Agroenvironnement (IRDA), 3300 rue Sicotte, C.P. 480, St-Hyacinthe, Québec, \\ J2S 7B8 Canada
}

Key words. Predation, aphids, Aphis spp., aphidophagous predators, Harmonia axyridis, Aphidoletes aphidimyza, spiders, apple orchard, biological control, conservation biological control

\begin{abstract}
A two-year field experiment was conducted to determine whether a conservation biological control strategy could be applied to enhance the biological control of green apple aphids, Aphis spp., in a high-density and scab-resistant apple orchard at the non-bearing stage. The natural occurrence of aphid predators and their impact on aphid populations were evaluated in 2005 . The impact of predation on aphid densities was evaluated by comparing a predator exclusion treatment with a control. In 2006, the possibility to enhance predator abundance/performance and aphid biological control with a flowering ground cover was tested: trees were grown either with a flowering ground cover of phacelia, Phacelia tanacetifolia Bentham, and buckwheat, Fagopyrum esculentum Moench, or with a conventional ground cover of mixed Poaceae species. In 2006, it was also determined whether aphid densities differ between Liberty and Topaz, 2 scab-resistant cultivars. Results indicate that the predatory arthropod community was dominated by Coccinellidae, Cecidomyiidae, and various spider species. The ladybird community was dominated by the exotic species Harmonia axyridis Pallas, and the abundance of this species was correlated with aphid density. Naturally occurring predators had little impact on aphid abundance, although the proportion of trees with aphid colonies was greater in the predator exclusion treatment on two consecutive dates in 2005. Ground cover types had no impact on aphid densities. The oviposition response of Cecidomyiidae to aphid density was greater in Liberty trees with flowering ground cover than with the conventional ground cover. Conversely, the response of ladybird adults to aphid density was more important in Topaz trees with the conventional ground cover than with the flowering ground cover. Finally, no difference occurred in aphid abundance between Liberty and Topaz trees. Those results are discussed from a biological control and ecological point of view.
\end{abstract}

\section{INTRODUCTION}

In Eastern North America, the most common aphid species in apple orchards are the green apple aphid, Aphis pomi de Geer and the spirea aphid, Aphis spiraecola Patch (Hemiptera: Aphididae). Those two species are hard to distinguish in the field and can be found in mixed colonies, and therefore will be referred to hereafter as green apple aphids. Even though green apple aphids are generally considered secondary pests in Quebec (Canada) apple orchards (Chouinard et al., 2001), severe infestation may curl leaves (Holdsworth, 1970), reduce tree growth and non-structural carbohydrate concentration in young apple trees (Kaakeh et al., 1992), and decrease fruit production (Hamilton et al., 1986). Severe infestation can also cause curling, stunting, and weakening of terminals, and increase risk of winter mortality (Oatman \& Legner, 1961). The negative impact of green apple aphids is likely to be more important on young than mature trees (Kaakeh et al., 1992). Keeping their populations under damaging levels is thus important.

The perennial nature of apple orchards has made this agroecosystem particularly attractive for studies in con- servation biological control. Conservation biological control aims at enhancing natural enemy densities within the orchard system, through attraction and/or retention (Landis et al., 2000; Altieri et al., 2005). This is generally achieved by increasing plant diversity or by implementing attractive (e.g. flowering) plant species. The potential to use conservation biological control against tree aphids has been evaluated in various orchard systems (see for example Haley \& Hogue, 1990; Bugg \& Waddington, 1994; Wyss, 1995; Wyss et al., 1995; Rice et al., 1998; Rieux et al., 1999), and results have been equivocal, with failures and successes. Wyss et al. (1995) observed lower densities of $A$. pomi and Dysaphis plantaginea (Passerini) in a managed orchard than in an unmanaged one, but mentioned that the management design they tested would probably have failed in a year of severe aphid infestation.

The goal of conservation biological control is to enable aphid natural enemies to significantly limit aphid population growth. However, it is still unclear how much apple aphid natural enemies affect Aphis spp. populations. Carroll \& Hoyt (1984) evaluated the impact of predators on apple aphid colonies using exclusion cages. This method demonstrated an overall treatment effect on aphid popula- 
tion growth. However, exclusion cages may also protect aphids against physical environmental conditions (e.g. rain or against wind) and therefore affect their population dynamics (see LeRoux, 1959; Dixon \& McKay, 1970). Cages also do not allow dispersal of winged aphids.

In promoting conservation biological control, it is hoped that an increased density of natural enemies within the orchard system will result in enhanced predation/parasitization of aphids. However, as Spellman et al. (2006) suggest, the food source available in managed vegetation (e.g. alternative prey, pollen, etc.) could reduce use of aphids by natural enemies.

The natural enemy complex of Aphis spp. has been extensively studied in North America (Oatman \& Legner, 1961; Holdsworth, 1970; Carroll \& Hoyt, 1984; Hagley \& Allen, 1990; Haley \& Hogue, 1990; Arnoldi et al., 1992; Tourneur et al., 1992; Brown, 2004). Combining measures of abundance and estimated impact, Brown (2004) identified Aphidoletes aphidimyza (Rondani) (Diptera: Cecidomyiidae), Harmonia axyridis Pallas (Coleoptera: Coccinellidae), and lacewing larvae (Neuroptera: Chrysopidae) as the predators with the highest biological control potential in West Virginia. Using a similar methodology, Hagley \& Allen (1990) identified lacewing larvae, adults of Coccinella septempunctata (L.), and adults of Campylomma verbasci (Meyer) (Hemiptera: Miridae) as potentially the most effective biological control agent of apple aphids in Ontario. However, being zoophytophagous, $C$. verbasci is also known as a pest of apples (Reding et al., 2001). Conservation management programs that enhance the abundance of ladybirds, lacewings and/or A. aphidimyza should thus be considered as useful for the biological control of apple aphids.

Another biological control strategy for apple orchards is the use of resistant cultivars. In Quebec, apple scab Venturia inaequalis (Cooke) is one of the most important diseases in apple orchards (Chouinard et al., 2001). The cultivars studied here, Liberty and Topaz, are two scabresistant cultivars that are currently being evaluated for their potential commercial use in Quebec. The susceptibility of different scab-resistant cultivars to major apple diseases/pests may vary widely. For example, the larvae of Ctenopseustis obliquana (Walker) (Lepidoptera: Tortricidae) do not develop on Granny Smith, Royal Gala, or Prima leaves, but do so on the scab-resistant Liberty leaves (Wearing \& Colhoun, 1999). Apple aphids are among pests whose populations may be influenced by cultivars (Underhill \& Cox, 1938; Oatman \& Legner, 1961; Kozár et al., 1994; Hogmire \& Miller, 2005; Angeli \& Simoni, 2006). Therefore, it is important to compare the susceptibility of Liberty and Topaz to Aphis spp.

The objectives of this experiment were thus (1) to survey aphid predators, and to evaluate whether naturally occurring foliage-dwelling predators have an impact on Aphis spp. population growth in a high-density and scabresistant apple orchard at the non-bearing stage, (2) to assess the potential of a newly established flowering ground cover to enhance aphid predators abundance and biological control of Aphis spp., and (3) to compare the susceptibility of the scab-resistant cultivars Liberty and Topaz to Aphis spp.

\section{MATERIAL AND METHODS}

\section{The experimental orchard}

The experiments were conducted during the 2005 and 2006 growing seasons in a $2,708 \mathrm{~m}^{2}$ non-bearing experimental orchard at Saint-Bruno-de-Montarville, Québec, Canada $\left(45^{\circ} 32^{\prime} \mathrm{N}, 73^{\circ} 20^{\prime} \mathrm{W}\right)$. The orchard had been planted in 2003 with seven scab-resistant cultivars (650 trees), from which two were selected for the experiment: Liberty, developed in North America and known for its high resistance to apple scab $V$. inaequalis and cedar apple rust Gymnosporangium juniperivirginianae Schwein (Khanizadeh \& Cousineau, 1998; Sandskar \& Gustafsson, 2004), and Topaz, a promising European scabresistant cultivar (Czynczyk et al., 2004). Both cultivars were grafted on M9 rootstock. The orchard consisted of 5 rows of 130 trees, and row and tree spacing were respectively $3.65 \mathrm{~m}$ and $1.25 \mathrm{~m}$, which corresponds to a high-density design. The orchard was not treated with insecticides or fungicides in either season. Herbicide was applied twice under the trees in order to control weed growth.

\section{The impact of predator exclusion (2005)}

The aim of the first trial (June $6^{\text {th }}$ to September $1^{\text {st }} 2005$ ) was to determine the influence of naturally occurring predation on apple aphid populations on Liberty and Topaz trees. Overall, 160 trees ( 80 of each cultivar) were sampled at each observation date. The trees were divided between two experimental treatments: (1) predation exclusion $(\mathrm{n}=64)$, where all foliagedwelling predators observed were manually removed twice a week, and (2) control $(\mathrm{n}=96)$, where no predator manipulation was done.

The exclusion of foliage-dwelling predators consisted of manually removing all the predators observed on trees at each observation period. Manual removal of predators was chosen instead of typical exclusion cages for 3 main reasons: (1) this allowed us to determine precisely which predators were removed from the trees, and thus to evaluate which predators have a potential impact on aphid colonies, (2) this permitted normal emigration of winged aphids which otherwise could not have escaped from exclusion cages, and would have caused overestimation of the impact of predator exclusion, and (3) this eliminated any protection from weather that exclusion cages may provide. However, this method can only estimate the effect of foliage-dwelling predators, and thus does not include the effect of non-resident predators that visit but then leave the trees (e.g. adult ladybirds). Moreover, some predators could go unnoticed during the observation period and escape removal, thus probably making exclusion partial.

Green apple aphids and predators were monitored twice a week. One shoot was randomly chosen and flagged on each tree. The same shoot was thereafter examined during each observation period. New shoots were chosen whenever a flagged shoot was defoliated or broken, or when leaves were too hardened to allow aphid establishment. New shoots were randomly selected, and preference was given to shoots bearing young unlignified leaves. From July $15^{\text {th }}$ to the end of the experiment, it was noted whether or not the inspected shoots were bearing young unhardened leaves or not.

The intensity of aphid infestation was assessed as the total number of aphids present on the first 6 apical leaves of each shoot examined. The number of aphids/shoot was expressed as an aphid density index, where $0=0$ aphids, $1=1-5$ aphids, $2=$ 
6-20 aphids, $3=21-50$ aphids, $4=51-100$ aphids, and $5=$ more than 100 aphids on a single shoot. Winged aphids were counted separately when present. All predators removed were identified and counted. Even though control trees were not inspected thoroughly for predators, adult ladybirds were identified and counted in order to estimate their relative abundance within the orchard.

\section{Statistical analyses}

The aphid density index and the number of winged aphids were compared between predator exclusion and control treatment using a 1-way MANOVA with repeated measures analysis on ranked data. No comparisons between cultivars are presented for 2005 since the vigour of Topaz trees was affected by the stress of shipment, resulting in a lower proportion of unlignified leaves in Topaz than in Liberty tress $(\mathrm{P}<0.05)$. The proportion of trees where an aphid colony was observed was compared between predator exclusion and control treatment for each cultivar and for each individual date using a Likelihood Ratio test. Aphid colonies were arbitrarily established as a grouping of 6 or more aphids on the first 6 apical leaves. Calculations were made using the statistical software JMP (SAS Institute, 2001).

\section{The impact of orchard floor management (2006)}

The aim of the second trial (May 29 $9^{\text {th }}$ to August $28^{\text {th }} 2006$ ) was (1) to evaluate the influence of ground cover on apple aphid and predator densities, and (2) to compare aphid densities between Liberty and Topaz trees. Overall, 64 trees were sampled on each observation date ( 32 Liberty and 32 Topaz trees). For each cultivar, half of the trees were grown on $7.2 \mathrm{~m} \times 8.5 \mathrm{~m}$ flowering grown cover patches of Phacelia, Phacelia tanacetifolia Bentham (Hydrophyllaceae), mixed with buckwheat, Fagopyrum esculentum Moench (Polygonaceae). The other half were grown on $7.2 \mathrm{~m} \times 8.5 \mathrm{~m}$ Lab Compagnon patches, which is a commercially sold standard ground cover mixture of Poaceae. All seeds were purchased at Labon inc. (Boucherville, QC, Canada). The two types of ground covers were in a checkerboard pattern, and two Liberty and two Topaz trees were observed in each ground cover unit.

Phacelia flowers are known to attract aphidophagous syrphid flies (Diptera: Syrphidae) (Hickman \& Wratten, 1996; Colley \& Luna, 2000; Ambrosino et al., 2006), while buckwheat has been reported to attract ladybirds (Ambrosino et al., 2006), syrphid flies (Colley \& Luna, 2000), and parasitoids (Stephens et al., 1998). Their impact on other aphidophagous predators and apple pests is poorly known.

Apple aphids and predators were monitored 3 times each week. For each tree inspected, two shoots randomly chosen among those bearing young unhardened leaves were examined. When shoots with young leaves were not available, shoots were randomly selected among all shoots. For each selected shoot, the first 6 leaves were inspected. The number of aphids on the most infested leaf was counted and reported as the number of aphids per shoot (Whitaker et al., 2006). The number of winged aphids present on the same leaf was counted separately. This method replaced the method previously used (in 2005) to increase the probability of finding aphid colonies.

Trees were also inspected visually for predatory arthropods. All shoots were inspected and all predators observed were noted. An additional 128 trees (for a total of 192, i.e. 96 Topaz and 96 Liberty) were carefully inspected for adult ladybirds, which were identified to species and counted. Half of the trees of each cultivar grew with flowering ground cover and the other half with conventional ground cover.

The proportion of young leaves available for aphid colonisation was evaluated for both cultivars throughout the season. For each tree, five shoots were randomly selected, and it was noted whether or not each of those shoots had young unhardened leaves, giving a score from 0 to 5 .

Statistical analyses

The influences of ground cover type and cultivars on aphid number per shoot (number of aphids on the first shoot + number of aphids on the second shoot / 2), winged aphid number per shoot (number of winged aphids on the first shoot + number of winged aphids on the second shoot / 2), and abundance spiders, adult ladybirds, and A. aphidimyza eggs and larvae were compared using a 2-way MANOVA with repeated measures analysis on ranked data (Zar, 1999). The proportion of trees where an aphid colony ( 6 aphids or more) was observed was compared between flowering and conventional ground cover treatment for each cultivar and for each individual date using a Likelihood Ratio test. The proportions of shoots bearing young leaves were transformed (arcsin squared-root), and 2-way MANOVA with repeated measures analysis was performed on ranked data (ground cover type and cultivar).

\section{RESULTS}

\section{The impact of predator exclusion (2005)}

Green apple aphid populations (Fig. 1)

The aphid density index and the abundance of winged aphids did not significantly differ between predator exclusion and control treatments for either Topaz or Liberty trees (MANOVA with repeated measures analysis; $\mathrm{P}$ $>0.05)$.

In Topaz, a greater proportion of trees with aphid colonies was detected in the predator exclusion than in the control treatment on July $18^{\text {th }}$ (Likelihood Ratio; $\chi^{2}=$ 10.077, d.f. $=1, \mathrm{P}=0.0015$ ) and July $21^{\text {st }}$ (Likelihood Ratio; $\chi^{2}=5.901$, d.f. $\left.=1, P=0.0151\right)$. On July $25^{\text {th }}$, the same trend (nearly significant) was observed (Likelihood Ratio; $\chi^{2}=3.835$ d.f. $=1, \mathrm{P}=0.0502$ ). In Liberty, the proportion of trees with aphid colonies was greater in the predator exclusion than in the control treatment on July $28^{\text {th }}$ (Likelihood Ratio; $\chi^{2}=4.080$, d.f. $=1, \mathrm{P}=0.0434$ ) and August $1^{\text {st }}$ (Likelihood Ratio; $\chi^{2}=4.310$, d.f. $=1, \mathrm{P}=$ 0.0379).

\section{Aphid predators}

Tables 1 and 2 show the main predators excluded from apple trees (those with $\geq 10$ individuals collected throughout the season on at least one cultivar). Throughout the season, a total of 529 predators (including eggs, larvae-nymphs, pupae, and adults) or potential predators (feeding habits of some Miridae and Pentatomidae could only be inferred) were excluded from Liberty and 325 from Topaz trees. The most numerous were ladybird adults, A aphidimyza eggs (mainly in Liberty), $A$. aphidimyza larvae, and spiders. The numbers of adult ladybirds, A. aphidimyza larvae and spiders excluded from trees were regressed against the mean aphid density index in the predator exclusion treatment. The relations were positive and significant for the 3 predators tested in Topaz trees (ladybirds, $\mathrm{r}^{2}=0.40 ;$ A. aphidimyza larvae, $\mathrm{r}^{2}$ $=0.16$; spiders, $\mathrm{r}^{2}=0.41$ ) and Liberty trees (ladybirds, $\mathrm{r}^{2}$ $=0.30 ; A$. aphidimyza larvae, $\mathrm{r}^{2}=0.32$; spiders, $\mathrm{r}^{2}=$ $0.40)$. 

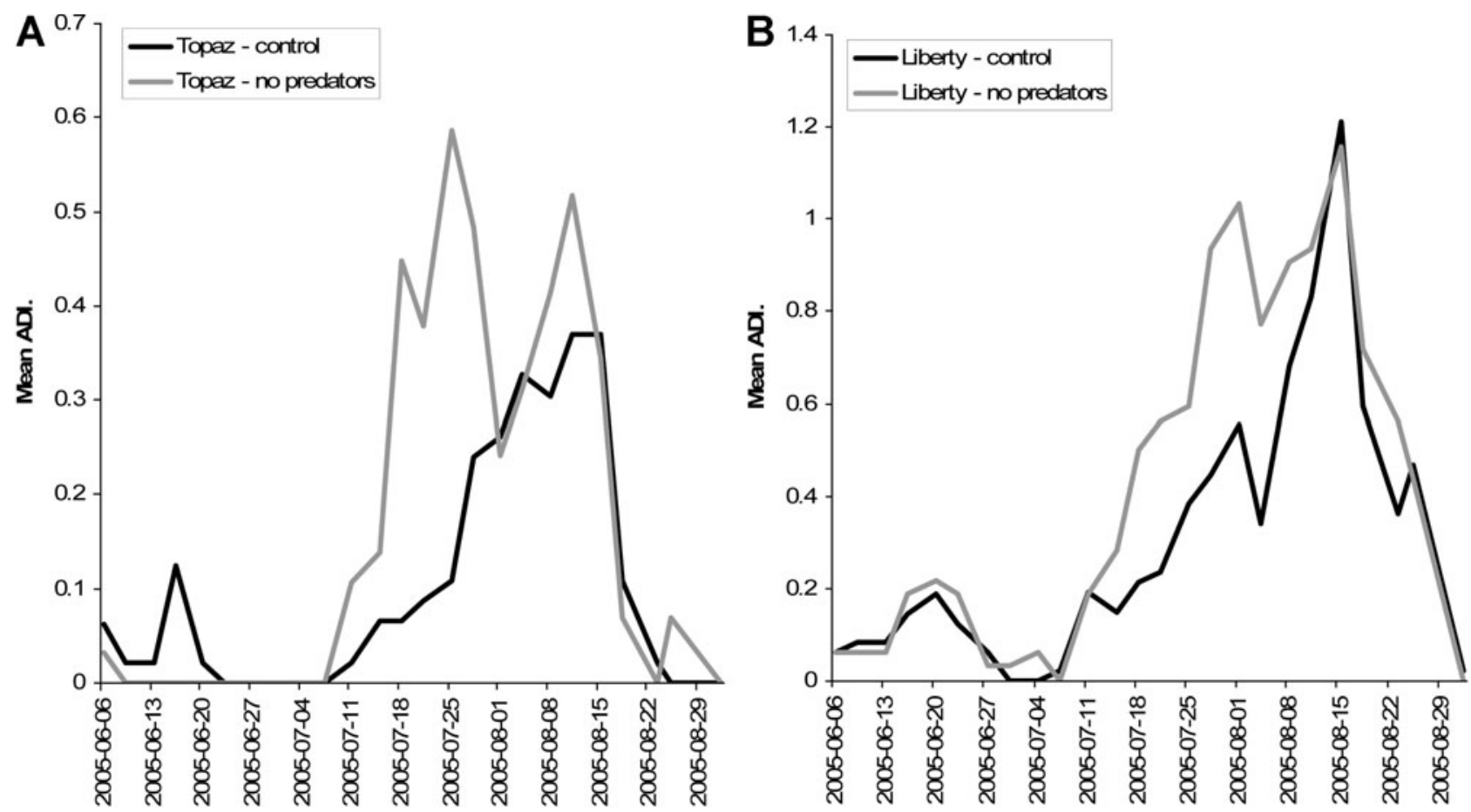

Fig. 1. The abundance of aphids throughout the 2005 season in (a) Topaz and (b) Liberty trees, with predators excluded or not, expressed as the mean aphid density index (ADI).

\section{Ladybird survey}

At least 6 species of adult ladybirds were observed throughout the season on apple trees: Coccinella trifasciata L., Coccinella septempunctata L., Coleomegilla maculata De Geer, Harmonia axyridis Pallas, Hippodamia spp., and Propylea quatuordecimpunctata (L.). Two species, C. trifasciata (1.06\% of total observations), and P. quatuordecimpunctata (1.59\%), as well as Hippodamia spp. (1.59\%) were not observed after July $7^{\text {th }}$, even though aphid population did not peak until August $15^{\text {th }}$. Coccinella septempunctata (4.23\%) was also mainly observed early in the season. Coleomegilla maculata $(4.76 \%)$ was rare, but more evenly observed throughout the season. Harmonia axyridis $(86.77 \%)$ was the dominant species, especially from July $25^{\text {th }}$ to August $15^{\text {th }}$. Regressions for each species of total counts against mean aphid density index for the whole orchard indicated nonsignificant slopes for all species except $H$. axyridis, which was positively and significantly related to mean aphid density index $\left(\mathrm{r}^{2}=0.37\right)$.

As for ladybird eggs and larvae, only those observed in the predator exclusion treatment were computed in the ladybird survey in order to avoid double counts. Only 8 egg clutches were removed in the predator exclusion treatment, 5 from unidentified species, 2 from $C$. maculata, and 1 from $H$. axyridis. Also, 24 ladybird larvae were excluded, with $62.50 \%$ C. maculata, $8.33 \% \mathrm{H}$. axyridis, $4.17 \%$ P. quatuordecimpunctata, and $25.00 \%$ unidentified individuals.

\section{The impact of orchard floor management (2006)}

Phacelia bloomed on June $7^{\text {th }}$ and buckwheat on June $14^{\text {th }}$. Both species remained in bloom until vegetation was mowed on July $28^{\text {th }}$.

\section{Green apple aphid populations (Fig. 2).}

The aphid number per shoot and the winged aphid number per shoot were not influenced by ground cover type and cultivar, and no interaction between ground cover type and cultivar was detected (2-way MANOVA with repeated measures analysis; $\mathrm{P}>0.05$ ).

For the Liberty cultivar, colonies were detected in a greater proportion of trees in the conventional than in the flowering ground cover on June $2^{\text {nd }}$ (Likelihood Ratio; $\chi^{2}$ $=6.119$, d.f. $=1, \mathrm{P}=0.0134)$, July $31^{\text {st }}$ (Likelihood Ratio; $\chi^{2}=4.470$, d.f. $\left.=1, \mathrm{P}=0.0345\right)$, and August $4^{\text {th }}$ (Likelihood Ratio; $\chi^{2}=4.700$, d.f. $=1, \mathrm{P}=0.0302$ ). The same

TABLE 1. Total numbers of predators excluded from Liberty trees in June, July, and August 2005. Predators were collected on 8 dates in each month. Cocc. $=$ Coccinellidae, A aphid.$=A$. aphidimyza, Chrys. $=$ Chrysopidae, Penta. $=$ Pentatomidae, Hemip. $=$ various Hemiptera other than Pentatomidae \& Reduviidae.

\begin{tabular}{lcccccccc}
\hline & $\begin{array}{c}\text { Cocc. } \\
\text { (larvae) }\end{array}$ & $\begin{array}{c}\text { Cocc. } \\
\text { (adults) }\end{array}$ & $\begin{array}{c}\text { A. aphid. } \\
\text { (eggs) }\end{array}$ & $\begin{array}{c}\text { A. aphid. } \\
\text { (larvae) }\end{array}$ & $\begin{array}{c}\text { Chrys. } \\
\text { (eggs) }\end{array}$ & $\begin{array}{c}\text { Penta. } \\
\text { (eggs) }\end{array}$ & $\begin{array}{c}\text { Hemip. } \\
\text { (adults) }\end{array}$ & Araneae \\
\hline June & 10 & 24 & 0 & 9 & 2 & 9 & 4 & 15 \\
July & 2 & 41 & 0 & 0 & 7 & 2 & 12 & 79 \\
August & 3 & 47 & 77 & 82 & 4 & 0 & 11 & 64 \\
\hline
\end{tabular}



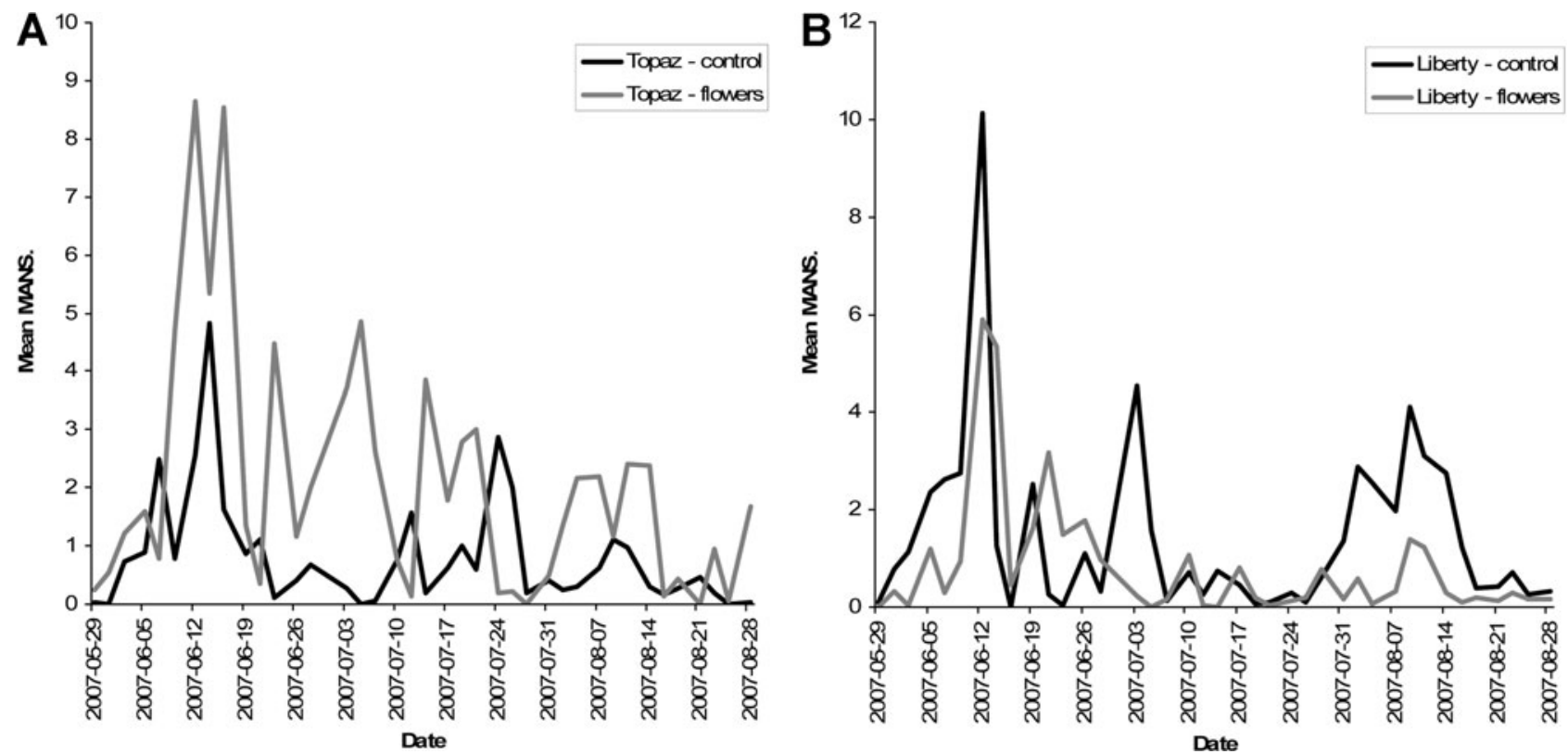

Fig. 2. The abundance of aphids throughout the 2006 season in (a) Topaz and (b) Liberty trees, with flowering or conventional ground cover, expressed as the mean aphid number per shoot.

was true for Topaz trees on June $21^{\text {st }}$ (Likelihood Ratio; $\chi^{2}=4.700$, d.f. $\left.=1, \mathrm{P}=0.0302\right)$. However, colonies were present in a greater proportion of Liberty trees with flowering than with conventional ground cover on June $23^{\text {rd }}$ (Likelihood Ratio; $\chi^{2}=4.470$, d.f. $=1, \mathrm{P}=0.0345$ ).

\section{Aphid predators}

Occurrence of the most numerous predators on each date is presented in Tables 3 and 4. For a given cultivar, at least twice as many $A$. aphidimyza eggs were observed throughout the season on trees with flowering ground cover than with conventional ground cover. Nevertheless, ground cover type and cultivar had no significant impact on the number of $A$. aphidimyza eggs and larvae (2-way MANOVA with repeated measures analysis; P $>0.05)$. Spider abundance was also independent of cultivar and ground cover type (2-way MANOVA with repeated measures analysis; $\mathrm{P}>0.05)$.

Aphidoletes aphidimyza eggs were positively and significantly correlated with aphid density in Topaz trees with conventional ground cover $\left(\mathrm{r}^{2}=0.56\right)$ and in Topaz trees with flowering ground cover $\left(r^{2}=0.46\right)$. The two slopes were not significantly different $(\mathrm{P}>0.05)$. The correlation was also positive and significant in Liberty trees with flowering ground cover $\left(\mathrm{r}^{2}=0.66\right)$. However, A. aphidimiza eggs were not significantly correlated with aphid density in Liberty trees with conventional ground cover $\left(r^{2}=0.08\right)$.

Abundance of spiders was positively and significantly correlated with aphid density in Liberty trees, both with flowering ground cover $\left(\mathrm{r}^{2}=0.13\right)$ and with conventional ground cover $\left(\mathrm{r}^{2}=0.15\right)$. Abundance of spiders did not differ between cover treatments $(\mathrm{P}>0.05)$. Spider abundance was not significantly correlated with aphid density in Topaz trees, either with flowering ground cover $\left(\mathrm{r}^{2}=\right.$ $0.07)$ or with conventional ground cover $\left(r^{2}=0.04\right)$.

\section{Adult ladybirds}

No differences in adult ladybird abundances were detected between cultivars and ground cover type (2-way MANOVA with repeated measures analysis; P > 0.05). For each date, mean aphid number per shoot was regressed against the sum of adult ladybirds for each cultivar and ground cover type (only the sum of the ladybirds present in trees where aphids were found was used). Adults ladybirds were significantly and positively correlated with aphid density in the Topaz trees with conventional ground cover $\left(\mathrm{r}^{2}=0.28\right)$, while they were not significantly correlated with aphids in the Topaz trees with flowering ground cover $\left(\mathrm{r}^{2}=0.03\right)$. The two regression coefficients are significantly different $(\mathrm{P}<0.05)$. Ladybirds were not significantly correlated with aphids in

TABLE 2. Total numbers of predators excluded from Topaz trees in June, July, and August 2005. Predators were collected on 8 dates in each month. Cocc. $=$ Coccinellidae, A aphid.$=$ A. aphidimyza, Chrys. $=$ Chrysopidae, Penta. $=$ Pentatomidae, Hemip. $=$ various Hemiptera other than Pentatomidae \& Reduviidae.

\begin{tabular}{lcccccccc}
\hline & $\begin{array}{c}\text { Cocc. } \\
\text { (larvae) }\end{array}$ & $\begin{array}{c}\text { Cocc. } \\
\text { (adults) }\end{array}$ & $\begin{array}{c}\text { A. aphid. } \\
\text { (eggs) }\end{array}$ & $\begin{array}{c}\text { A. aphid. } \\
\text { (larvae) }\end{array}$ & $\begin{array}{c}\text { Chrys. } \\
\text { (eggs) }\end{array}$ & $\begin{array}{c}\text { Penta. } \\
\text { (eggs) }\end{array}$ & $\begin{array}{c}\text { Hemip. } \\
\text { (adults) }\end{array}$ & Araneae \\
\hline June & 0 & 11 & 0 & 0 & 4 & 6 & 7 & 20 \\
July & 2 & 35 & 4 & 7 & 8 & 0 & 23 & 70 \\
August & 7 & 21 & 0 & 14 & 6 & 0 & 10 & 51 \\
\hline
\end{tabular}


TABLE 3. The mean number of predators observed in Liberty trees on each observation date in June, July, and August 2006. Predators were observed on 12 dates in June and August, and 13 in July. Cocc. $=$ Coccinellidae, A. aphid. $=$ A. aphidimyza, Chrys. $=$ Chrysopidae, Penta. $=$ Pentatomidae, Red. $=$ Reduviidae, Flower $=$ flowering ground cover, conventional $=$ conventional ground cover.

\begin{tabular}{lcccccccc}
\hline & $\begin{array}{c}\text { Ground } \\
\text { cover }\end{array}$ & $\begin{array}{c}\text { Cocc. } \\
\text { (larvae) }\end{array}$ & $\begin{array}{c}\text { Cocc. } \\
\text { (adults) }\end{array}$ & $\begin{array}{c}\text { A. aphid. } \\
(\mathrm{eggs})\end{array}$ & $\begin{array}{c}\text { A. aphid. } \\
\text { (larvae) }\end{array}$ & $\begin{array}{c}\text { Penta. } \\
\text { (eggs) }\end{array}$ & $\begin{array}{c}\text { Red. } \\
\text { (nymphs) }\end{array}$ & Araneae \\
\hline \multirow{2}{*}{ June } & conventional & 0.17 & 3.42 & 9.00 & 2.25 & 0.42 & 0.00 & 2.08 \\
& flower & 1.50 & 1.83 & 25.33 & 3.50 & 1.17 & 0.00 & 2.67 \\
\multirow{2}{*}{ July } & conventional & 0.15 & 1.15 & 0.46 & 0.08 & 1.77 & 0.54 & 1.00 \\
& flower & 0.15 & 0.77 & 0.00 & 0.54 & 0.62 & 0.08 & 1.08 \\
\multirow{2}{*}{ August } & conventional & 0.00 & 0.75 & 0.00 & 0.00 & 0.00 & 1.33 & 1.17 \\
& flower & 0.00 & 0.58 & 0.00 & 0.00 & 0.17 & 0.25 & 0.67 \\
\hline
\end{tabular}

the Liberty trees with conventional $\left(\mathrm{r}^{2}=0.02\right)$ or flowering ground cover $\left(\mathrm{r}^{2}=0.07\right)$, and the regression coefficients were not significantly different $(\mathrm{P}>0.05)$.

\section{Ladybird survey}

Throughout the season, a total of 546 ladybird adults were observed, which belonged to only 4 species: $C$. septempunctata, C. maculata, H. axyridis, and P. quatuordecimpunctata. The relative patterns of abundance were similar to 2005. Again, H. axyridis was the dominant species throughout the season $(79.12 \%$ of the total observations). Coccinella septempunctata $(11.72 \%)$ and $P$. quatuordecimpunctata $(3.30 \%)$ were mainly present in the early season, while C. maculata $(4.40 \%)$ was observed until July $31^{\text {st }}$. Some ladybirds $(1.47 \%)$ fell or flew away before being identified. Regressions for each species between total counts and mean aphid number per shoot yielded a significantly positive relation for $C$. septempunctata $\left(\mathrm{r}^{2}=0.26\right)$ and $H$. axyridis $\left(\mathrm{r}^{2}=0.37\right)$. Regressions were not significant for $P$. quatuordecimpunctata and C. maculata.

Young leaves availability

The proportion of young leaves available for aphid colonisation did not differ between the cultivars and ground cover types (2-way MANOVA with repeated measures; $\mathrm{P}>0.05$ ).

\section{DISCUSSION}

This paper reports two trials performed in a young, high-density, and scab-resistant apple orchard. The first aimed at determining the role of naturally occurring foliage-dwelling predators in suppressing aphid populations, and the second explored the possibility of enhancing predator populations by growing a flowering ground-cover.

The results of the 2005 trial indicate that naturally occurring predators had little impact on apple aphid populations. The general abundance of aphids was not different between predator exclusion and control treatments throughout the season. However, the proportion of trees where an aphid colony (6 aphids or more) was detected was greater in the predator exclusion than in the control treatments on two consecutive dates in both Liberty and Topaz cultivars, during a period of rapid aphid population growth. Since only the predators that were observed on the foliage were manually excluded, predator exclusion was probably only partial, and many highly mobile predators (such as adult ladybirds) may have attacked aphid colonies between observations without being detected. The results presented here thus mainly indicate the aphid control potential of foliage-dwelling predators, such as ladybird larvae and $A$. aphidimyza larvae. It can thus be said that foliage-dwelling predators had an impact on the number of colonies during aphid population rapid growth phase, but did not prevent aphid populations from reaching similar densities to those in the predator exclusion treatment.

Our results indicate that the presence of a flowering ground cover of phacelia and buckwheat had no impact on aphid populations and predator abundance. However, the absence of a flowering ground cover had a negative impact on A. aphidimyza oviposition in the Liberty cul-

TABLE 4. The mean number of predators observed in Topaz trees on each observation date in June, July, and August 2006. Predators were observed on 12 dates in June and August, and 13 in July. Cocc. $=$ Coccinellidae, A. aphid. $=$ A. aphidimyza, Chrys. $=$ Chrysopidae, Penta. $=$ Pentatomidae, Red. $=$ Reduviidae, Flower $=$ flowering ground cover, conventional $=$ conventional ground cover.

\begin{tabular}{lcccccccc}
\hline & $\begin{array}{c}\text { Ground } \\
\text { cover }\end{array}$ & $\begin{array}{c}\text { Cocc. } \\
\text { (larvae) }\end{array}$ & $\begin{array}{c}\text { Cocc. } \\
\text { (adults) }\end{array}$ & $\begin{array}{c}\text { A. aphid. } \\
\text { (eggs) }\end{array}$ & $\begin{array}{c}\text { A. aphid. } \\
\text { (larvae) }\end{array}$ & $\begin{array}{c}\text { Penta. } \\
\text { (eggs) }\end{array}$ & $\begin{array}{c}\text { Red. } \\
\text { (nymphs) }\end{array}$ & Araneae \\
\hline \multirow{2}{*}{ June } & conventional & 0.08 & 2.25 & 11.17 & 0.58 & 0.50 & 0.00 & 2.58 \\
\multirow{4}{*}{ July } & flower & 0.17 & 1.25 & 45.00 & 4.25 & 1.33 & 0.00 & 1.33 \\
& conventional & 0.08 & 1.54 & 0.08 & 0.31 & 1.00 & 0.00 & 1.62 \\
\multirow{2}{*}{ August } & flower & 0.23 & 1.08 & 1.62 & 0.85 & 1.08 & 0.08 & 1.08 \\
& conventional & 0.00 & 0.75 & 0.00 & 0.00 & 0.08 & 0.08 & 1.58 \\
\hline
\end{tabular}


tivar : the relationship between aphid density and $A$. aphidimyza was weaker in Liberty trees with the conventional ground cover than those with the flowering ground cover. No such difference was observed for Topaz trees. Adult $A$. aphidimyza are known to feed on aphid honeydew (Nijveldt, 1988), but to the authors' knowledge, feeding on flower nectar has never been reported. Whether or not $A$. aphidimyza adults feed from $P$. tanacetifolia and/or $F$. esculentum flowers remains to be tested. Also, whether enhanced A. aphidimyza oviposition resulted from an enhanced density of females and/or from enhanced female fecundity should also be determined. An alternative hypothesis could be that $A$. aphidimyza eggs suffer less from intraguild predation on trees with flowering ground cover than on control trees due to presence of alternative food sources.

In contrast to density of $A$. aphidimyza, ladybird adult density seemed either uninfluenced or negatively influenced by the flowering ground cover of phacelia and buckwheat. Whether adult ladybirds were attracted to phacelia/buckwheat pollen or nectar or to the fauna associated with those plants remains to be tested. Spellman et al. (2006) hypothesized that the alternative food sources provided by conservation biological control could have a negative impact on ladybird predation by diverting individuals from the aphid resource. Their glasshouse experiment, however, indicated that buckwheat did not interfere with $H$. axyridis predation, but no data are available for phacelia.

The fact that spiders were one of the most abundant groups observed in the predator exclusion experiment raises the question as to the role spiders play in aphid biological control in the apple ecosystem. The main spiders present on apple trees were hunting spiders, both ambush and cursorial (Salticidae, Thomisidae, Clubionidae). We twice observed individuals of Clubionidae feeding on aphids (one apterous and one winged aphid). Thomisidae have been reported to feed on aphids in other systems (Romero \& Vasconcellos-Neto, 2003). Brown et al. (2003) observed that Thomisidae are more active around midnight in West Virginia apple orchards; since our survey was made during daylight, the abundance and activity of Thomisidae may thus have been underestimated. However, hunting spiders are not generally considered important aphid predators in apple trees, and some authors have suggested that spiders could even have a negative impact on biological control due to intraguild predation (see Carroll \& Hoyt, 1984; Hodge, 1999; Nyffeler \& Sunderland, 2003).

Hunting spiders could also indirectly influence aphid density through predation on aphid-tending ants. Sanders \& Platner (2007) observed that spiders could have a negative impact on the presence of certain ants species. In our experiment, Clubionidae and Thomisidae were (anecdotally) observed feeding on ants, presumably Lasius sp. The effects of spiders on aphid populations could thus be (1) direct through predation on aphids and/or (2) indirect through predation on ants, thus relaxing ant-tending. The role of spiders in aphid suppression should be further investigated.

Even though ladybird adults were abundant throughout both seasons, eggs and larvae were rarely seen. Tourneur et al. (1992) also mentioned that few ladybird larvae are found within aphid colonies in Quebec apple orchards. According to Carroll \& Hoyt (1984), ladybird eggs and larvae seemed to be mainly associated with $D$. plantaginea and Eriosoma lanigerum (Haussman) in young apple trees in Washington state. Those two species were all but absent from our experimental trees, which could provide an explanation for the low oviposition response of ladybirds in this study.

The ladybird survey indicated that the exotic species $H$. axyridis was the dominant species in the experimental apple orchard in both years and that adults of this species showed the strongest numerical response to aphid densities. The dominance of $H$. axyridis has been previously demonstrated in West Virginia orchards (Brown, 2003). Lucas et al. (2007) reported that $H$. axyridis is now part of the complex of ladybird species in Quebec apple orchards, with 64\% (1999) and 12\% (2000) of the ladybirds captured. In our survey $H$. axyridis was even more dominant (86.77\% in 2005 and $79.12 \%$ in 2006). Many differences exist between the earlier survey and that presented here, the most important being the dates (1999-2000 vs 2005-2006), the geographical location (Henryville $\quad 45^{\circ} 8^{\prime} \mathrm{N}, \quad 73^{\circ} 11^{\prime} \mathrm{W}$ vs St-Bruno-deMontarville $45^{\circ} 32^{\prime} \mathrm{N}, 73^{\circ} 20^{\prime} \mathrm{W}$ ), and the methodology employed (sticky traps and tapping vs visual observations).

Aphidoletes aphidimyza has several times been observed as the numerically dominant species of aphid predators in North American apple orchards (Haley \& Hogue, 1990; Kozár et al., 1994; Stewart \& Walde, 1997; Brown, 2004). According to Bouchard et al. (1982), A. aphidimyza may be present in Quebec orchards from late May or early June. In our experiment, however, $A$. aphidimyza larvae were abundant in mid-June 2006 and only from early to mid August 2005 when aphid populations peaked. Stewart \& Walde (1997) suggested that $A$. aphidimyza could have a great impact on apple aphid colonies in northern climates (such as in Canada) due to the fact that it begins its activities while aphid colonies are still at low density. Our results suggest that even if $A$. aphidimyza adults are present early in the season, females will not lay eggs in aphid colonies until they reach high densities. This oviposition behaviour would be advantageous for the small and vulnerable larvae of this species, which would benefit from a dilution effect when present in high density aphid colonies, hence reducing the risk of intraguild predation (Lucas \& Brodeur, 2001).

Syrphids, which are known to be attracted to phacelia (Ambrosino et al., 2006; Hickman \& Wratten, 1996), were virtually absent from the system. Some authors have reported syrphids to be early colonisers of aphid colonies (Bouchard et al., 1982; Carroll \& Hoyt, 1984; Chambers, 1991; Miñarro et al., 2005) and have noted that they could suffer from intraguild predation later in the season 
(Carroll \& Hoyt, 1984). In our study, syrphids could have gone unnoticed if they were present (and disappeared) before our first sampling date. Holdsworth (1970) also observed that syrphids were mainly associated with $D$. plantaginea and Rhopalosiphum fitchii (Sanderson), colonies of which build up earlier than those of $A$. pomi in Ohio apple orchards. Those two aphid species were not present in our experimental orchard. In contrast to other studies, Oatman \& Legner (1961) observed that syrphids were the most abundant immature predators in $A$. pomi colonies in Wisconsin apple orchards, and were present throughout the season.

In conclusion, this study demonstrated that foliagedwelling predators only have a limited impact on Aphis spp. populations in a young, high-density, and scabresistant apple orchard located in southern Quebec. A flowering ground cover of phacelia and buckwheat also had little impact on predator and aphid abundances. The flowering ground cover seemed to have a positive impact on A. aphidimyza oviposition, but this species colonised only well established (high density) aphid colonies, thereby reducing its impact as a biological control agent. Conversely, the flowering ground cover seemed to reduce the response of adult ladybirds to aphid density. Both Liberty and Topaz cultivars were equally susceptible to aphid infestations.

ACKNOWLEDGEMENTS. We would like to thank J. Tardif, C. Lemieux, and V. Proulx for technical assistance on the field, M. R.-Fréchette for help in computing the data, and P. PeresNeto and J. Brodeur for helpful suggestions about the manuscript. The project was funded by the Fonds de Recherche sur la Nature et les Technologies (Quebec Government).

\section{REFERENCES}

Altieri M.A., Nicholls C.I., Ponti L. \& York A. 2005: Designing biodiverse, pest-resilient vineyards through habitat management. Pract. Winery Vineyard 27: 16-30.

Ambrosino M.D., Luna J.M., Jepson P.C. \& Wratten S.D. 2006: Relative frequencies of visits to selected insectary plants by predatory hoverflies (Diptera: Syrphidae), other beneficial insects, and herbivores. Environ. Entomol. 35: 394-400.

Angeli G. \& Simoni S. 2006: Apple cultivars acceptance by Dysaphis plantaginea Passerini (Homoptera: Aphididae). J. Pest Sci. 79: 175-179.

Arnoldi D., Stewart R.K. \& Boivin G. 1992: Predatory mirids of the green apple aphid Aphis pomi, the two-spotted spider mite Tetranychus urticae and the European red mite Panonychus ulmi in apple orchards in Québec. Entomophaga 37: 283-292.

Bouchard D., Tourneur J.-C. \& Paradis R.O. 1982: Le complexe entomophage limitant les populations d'Aphis pomi de Geer (Homoptera: Aphididae) dans le sud-ouest du Québec. Données préliminaires. Ann. Soc. Entomol. Québec 27: 80-93.

BRown M.W. 2003: Intraguild responses of aphid predators on apple to the invasion of an exotic species, Harmonia axyridis. BioControl 48: 141-153.

BRown M.W. 2004: Role of aphid predator guild in controlling spirea aphid population on apple in West Virginia, USA. Biol. Control 29: 189-198.
Brown M.W., Schmitt J.J. \& Abraham B.J. 2003: Seasonal and diurnal dynamics of spiders (Aranea) in West Virginia orchards and the effect of orchard management on spider communities. Environ. Entomol. 32: 830-839.

BugG R.L. \& Waddington C. 1994: Using cover crops to manage arthropod pests of orchards: a review. Agr. Ecosyst. Environ. 50: 11-28.

Carroll D.P. \& Hoyt S.C. 1984: Natural enemies and their effects on apple aphid, Aphis pomi DeGeer (Homoptera: Aphididae), colonies on young apple trees in central Washington. Environ. Entomol. 13: 469-481.

Chambers R.J. 1991: Oviposition by aphidophagous hoverflies (Diptera: Syrphidae) in relation to aphid density and distribution in winter wheat. In Polgar L., Chambers R.J., Dixon A.F.G. \& Hodek I. (eds): Behaviour and Impact of Aphidophaga. SPB Academic Publishing, The Hague, pp. 115-121.

Chouinard G., Morin Y. \& Brodeur C. 2001: Lutte contre les insectes et acariens. In Chouinard G. (ed.): Guide de Gestion Intégrée des Ennemis du Pommier. Centre de référence en agriculture et agroalimentaire du Québec, Sainte-Foy, Québec, pp. 99-138.

Colley M.R. \& LunA J.M. 2000: Relative attractiveness of potential beneficial insectary plants to aphidophagous hoverflies (Diptera: Syrphidae). Environ. Entomol. 29: 1054-1059.

Czynczyk A., Mika A., Bielicki P. \& Krawiec A. 2004: Evaluation of apple cultivars for sustainable fruit production. J. Fruit Ornam. Plant Res. (Special Ed.) 12: 251-256.

Dixon A.F.G. \& MCKAY S. 1970: Aggregation in the sycamore aphid Drepanosiphum platanoides (Schr.) (Hemiptera: Aphididae) and its relevance to the regulation of population growth. J. Anim. Ecol. 39: 439-454.

Hagley E.A.C. \& Allen W.R. 1990: The green apple aphid, Aphis pomi Degeer (Homoptera: Aphididae), as prey of polyphagous arthropod predators in Ontario. Can. Entomol. 122: $1221-1228$.

Haley S. \& Hogue E.J. 1990: Ground cover influence on apple aphid, Aphis pomi DeGeer (Homoptera: Aphididae), and its predators in a young apple orchard. Crop Prot. 9: 225-230.

Hamilton G.C., Swift F.C. \& Marini R. 1986: Effect of Aphis pomi (Homoptera: Aphididae) density on apples. J. Econ. Entomol. 79: 471-478.

Hickman J.M. \& Wratten S.D. 1996: Use of Phacelia tanacetifolia strips to enhance biological control of aphids by hoverfly larvae in cereal fields. J. Econ. Entomol. 89: 832-840.

Hodge M.A. 1999: The implications of intraguilde predation for the role of spiders in biological control. J. Arachnol. 27: 351-362

Hogmire H.W. \& Miller S.S. 2005: Relative susceptibility of new apple cultivars to arthropod pests. HortScience 40: 2071-2075.

HoldswORTh R.P. JR. 1970: Aphids and aphid enemies: effect of integrated control in an Ohio apple orchard. J. Econ. Entomol. 63: 530-535.

KaAkeh W., Pfeiffer D.G. \& Marini R.P. 1992: Combined effects of spirea aphid (Homoptera: Aphididae) and nitrogen fertilization on shoot growth, dry matter accumulation, and carbohydrate concentration in young apple trees. J. Econ. Entomol. 85: 496-506.

Khanizadeh S. \& Cousineau J. 1998: Our Apples. Agriculture and Agri-Food Canada, St-Jean-sur-le-Richelieu, Quebec, 260 pp.

KozÁr F., Brown M.W. \& Lightner G. 1994: Spatial distribution of homopteran pests and beneficial insects in an orchard and its connection with ecological plant protection. J. Appl. Entomol. 117: 519-529. 
Landis D.A., Wratten S.D. \& Gurr G.M. 2000: Habitat management to conserve natural enemies of arthropod pests in agriculture. Annu. Rev. Entomol. 45: 175-201.

LeRoux E.J. 1959: Effects of frost, rainfall, and aestival temperature on populations of the apple aphid, Aphis pomi DeG (Homoptera: Aphididae), on apple in Quebec. Ann. Soc. Entomol. Québec 5: 49-52.

Lucas É. \& Brodeur J. 2001: A fox in sheep's clothing: furtive predators benefit from the communal defense of their prey. Ecology 82: 3246-3250.

Lucas É., Vincent C., Labrie G. Chouinard G., Fournier F., Pelletier F., Bostanian N.J., Coderre D., Mignault M.-P. \& Lafontaine P. 2007: The multicolored Asian ladybeetle Harmonia axyridis (Coleoptera: Coccinellidae) in Quebec agroecosystems ten years after its arrival. Eur. J. Entomol. 104: $737-743$

Miñarro M., Hemptinne J.-L. \& Dapena E. 2005: Colonization of apple orchards by predators of Dysaphis plantaginea: sequential arrival, response to prey abundance and consequences for biological control. BioControl 50: 403-411.

Nijveldt W. 1988: Cecidomyiidae. In Minks A.K., Harrewijn P. \& Helle W. (eds): World Crop Pests. Aphids. Vol. $2 B$. Elsevier, New York, pp. 271-277.

NyfFeleR M. \& Sunderland K.D. 2003: Composition, abundance and pest control potential of spider communities in agroecosystems: a comparison of European and US studies. Agr. Ecosyst. Environ. 95: 579-612.

OAtman E.R. \& Legner E.F. 1961: Bionomics of the apple aphid, Aphis pomi, on young nonbearing apple trees. J. Econ. Entomol. 54: 1034-1037.

Reding M.E., Beers E.H., Brunner J.F. \& Dunley J.E. 2001: Influence of timing and prey availability on fruit damage to apple by Campylomma verbasci (Hemiptera: Miridae). $J$. Econ. Entomol. 94: 33-38.

Rice N.R., Smith M.W., Eikenbary R.D., Arnold D., Tedders W.L., Wood B., Landgraf B.S., Taylor G.G. \& Barlow G.E. 1998: Assessment of legume and nonlegume ground covers on Coleoptera: Coccinellidae density for low-input pecan management. Am. J. Alternative Agr. 13: 111-123.

Rieux R., Simon S. \& Defrance H. 1999: Role of hedgerows and ground cover management on arthropod population in pear orchards. Agr. Ecosyst. Environ. 73: 119-127.

Romero G.Q. \& VASCONCELLOS-NETO J. 2003: Natural history of Misumenops argenteus (Thomisidae): seasonality and diet on Trichogoniopsis adenantha (Asteraceae). J. Arachnol. 31: 297-304.
Sanders D. \& Platner D. 2007: Intraguild interactions between spiders and ants and top-down control in a grassland food web. Oecologia 150: 611-624.

SANDSKAR B. \& GustafsSon M. 2004: Classification of apple scab resistance in two assortment orchards. Genet. Resour. Crop Ev. 51: 197-203.

SAS Institute 2001: JMP IN®, Version 4. Start Statistics: a Guide to Statistics and Data Analyses Using JMP ${ }^{\circledR}$ and JMP $I N ®$ Software. Duxbury, Pacific Grove, California, 656 pp.

Spellman B., Brown M.W. \& Mathews C.R. 2006: Effect of floral and extrafloral resources on predation of Aphis spiraecola by Harmonia axyridis on apple. BioControl 51: 715-724.

Stephens M.J., France C.M., Wratten S.D. \& Frampton C. 1998: Enhancing biological control of leafrollers (Lepidoptera: Tortricidae) by sowing buckwheat (Fagopyrum esculentum) in an orchard. Biocontrol Sci. Techn. 8: 547-558.

Stewart H.C. \& Walde S.J. 1997: The dynamics of Aphis pomi De Geer (Homoptera: Aphididae) and its predator, Aphidoletes aphidimyza (Rondani) (Diptera: Cecidomyiidae), on apple in Nova Scotia. Can. Entomol. 129: 627-636.

Tourneur J.-C., Bouchard D. \& Pilon J.-G. 1992: Le complexe des ennemis naturels des pucerons en pommeraie au Québec. In Vincent C. \& Coderre D. (eds): La Lutte Biologique. Gaëtan Morin, Boucherville, Québec, pp. 179-193.

UNDERHILL G.W. \& Cox J.A. 1938: Studies on the resistance of apple to the woolly apple aphid, Eriosoma lanigerum (Hausm.). J. Econ. Entomol. 31: 622-625.

WEARING C.H. \& COLHOUN K. 1999: Bioassays for measuring the resistance of different apple cultivars to the development of leafrollers (Lepidoptera: Tortricidae). N. Z. J. Crop Hort. 27: 91-99.

Whitaker P.M., Mahr D.L. \& Clayton M. 2006: Verification and extension of a sampling plan for apple aphid, Aphis pomi DeGeer (Hemiptera: Aphididae). Environ. Entomol. 35: 488-496.

Wyss E. 1995: The effects of weed strips on aphids and aphidophagous predators in an apple orchard. Entomol. Exp. Appl. 75: 43-49.

Wyss E., Niggli U. \& Nentwig W. 1995: The impact of spider on aphid populations in a strip-managed apple orchard. $J$. Appl. Entomol. 119: 473-478.

ZAR J.H. 1999: Biostatistical Analysis. 4th ed. Prentice Hall, Upper Saddle River, New Jersey, 931 pp.

Received September 18, 2007; revised and accepted March 4, 2008 